\title{
ENGLISH TEACHERS' PERCEPTIONS AND IMPLEMENTATION OF PEDAGOGICAL CONTENT KNOWLEDGE IN TEACHING ENGLISH TO YOUNG LEARNERS
}

\author{
Ni Made Sukreni Virgianti ${ }^{1}$, I G A Lokita Purnamika Utami ${ }^{2}$, Kadek Sintya Dewi ${ }^{3}$ \\ Prodi Pendidikan Bahasa Inggris, \\ Universitas Pendidikan Ganesha, Singaraja, Indonesia \\ e-mail: sukreniv@gmail.com¹, lokitapurnamika@undiksha.ac.id², \\ sintyadewi@undiksha.ac.id ${ }^{3}$
}

\begin{tabular}{|l|l|l|}
\hline (C) $\left(\begin{array}{l}\text { BY } \\
\text { SA }\end{array}\right.$ & $\begin{array}{l}\text { This is an open-access article under the CC BY-SA license. } \\
\text { Copyright } \odot 2020 \text { by Author. Published by Universitas Pendidikan Ganesha. }\end{array}$ \\
\hline Received : August, 2020 & Accepted : November, 2020 & Published : December, 2020 \\
\hline
\end{tabular}

\begin{abstract}
This study aimed at investigating primary English teachers' perceptions and implementation of Pedagogical Content Knowledge in teaching English to young learners, and the consistency between the teachers' perceptions and implementation of Pedagogical Content Knowledge in teaching English to young learners. This study involved three English teachers from three different primary schools in Buleleng regency which were selected by using Convenience sampling technique. The research design was mixed method. The type of mixed method used in this study was an embedded mixed method which was dominated by qualitative. The instruments used to collect the data were questionnaire, observation sheet, and interview guide. The data were analyzed by using descriptive qualitative. The study demonstrated that teachers had high perceptions of PCK. However, their PCK implementation was very low. Thus, there is no consistency between perceptions and implementation of PCK. Moreover, based on the result of interview, the teachers encountered some problems including difficulty in speaking and writing English, designing learning activities for the students, choosing media that related to the material, and providing learning meadia due to lack of facility in the school. Therefore, the teachers need to improve their pedagogical content knowledge by participating in certain professional development program.
\end{abstract}

Keywords: Pedagogical Content Knowledge, Teachers' perceptions, Primary School.

\section{INTRODUCTION}

In this globalization era, English has become the foremost tool of global communication and the most important thing for acquiring access to the world's intellectual, cultural, and technical resources. It can be said that English has important role in society. It is in line with Reddy (2016) who stated that the importance of English can be seen through several aspects including business and education. English is important in business field since it can build international collaboration. In education field, the university students will be easier to get more knowledge since most of the books are written and translated into English.

Relating to the importance of English in society, it is better to learn English as early as possible to get the better result. As stated by Ghasemi and Hashemi (2011) children 


\section{PRASI JURnAL BAHASA, SENI, DAN PENGAJARANNYA \\ VOL. 15 | No. 02 | December 2020 \\ ISSN: Print 1693-6124 - Online 2614-1116}

Undiksha| DOI: http://dx.doi.org/10.23887/prasi.v15i02.28161 |https://ejournal.undiksha.ac.id/index.php/PRASI

learn language better and faster. It is in line with Jean Piaget who proposed children development theory that stated children are active learners and thinkers where they can easily acquire new language (as cited in Shin, 2009). Thus, the earlier of the learning English, the better of the result will be.

Teaching English as early as possible is suggested in order to achieve better result. However, in curriculum 2013, English subject is not a compulsive subject in primary school. However, it still can be taught if it is contextually needed. For the real example, there are some primary schools in Bali provides English subject for the students. It is because Bali is an international tourist destination which requires the people to speak English. Besides, English is also important because it can help people to find job in tourism field.

The elimination of English as a complusive subject in primary school cause several problems. First, there is no national standardization in terms of instructional set for teaching English in primary school. The school that still provide English make their own policy based on the school management. Consequently, most of the primary schools hire PGSD (Primary School Teacher Education) graduate teachers to teach English. These teachers do not have sufficient background knowledge about English. Additionally, the teachers who are responsible for teaching English in primary school do not have special qualification to teach English to young learners (Listyariani, Artini, \& Padmadewi, 2018). Furthermore, Habibi and Sofwan (2015) also stated that most of teachers who teach English to young learners are not qualified enough in terms of professional and pedagogical competence.

Regarding to this issue, the primary school English teachers must have the knowledge about the content that they teach, the knowledge about young learners' characteristics that will help to design learning activity, and the knowledge about the teaching strategy to teach English to young learners. This knowledge is known as Pedagogical Content Knowledge or PCK. PCK is the combination of teachers' knowledge about the subject or learning content and the knowledge about the strategy that is used to teach the subject to the students. There are several aspects of PCK, namely knowledge of subject matter, knowledge of young learners' characteristics, and knowledge of instructional strategy for young learners (Magnusson, Krajcik, \& Borko, 1999; Shulman, 1986).

According to Shulman (1986) subject matter knowledge is the representation of the teachers related to the subject that is taught. Besides, Faisal (2015) defined subject matter knowledge as the teachers' deep understanding of the subject itself includes the concept and the systematical structure of the subject. In EFL context, subject matter knowledge consists of two aspects namely language awareness and language proficiency. Andrews (2001) explained language awareness as the teachers' knowledge related to the system of the language which includes grammar, phonology, lexis, and discourse. By having a good language awareness, the teachers will be able to correct the students' problems in grammar, pronunciation, and enrich the students' vocabulary. Meanwhile, language proficiency is the teachers' ability in using the language to explain the material and communicate with the students in spoken and written form. In line with it, Canh and Renandya (2017) stated that the teachers who have a good language proficiency will give better learning and be considered to be more competent in providing input for the students. 
Moreover, primary school English teachers must have knowledge about the characteristics of young learners in order to design activity that can facilitate their characteristics and achieve the learning objectives. In relation, Faisal (2015) described the knowledge of young learners' characteristics as the knowledge of learners' learning style, needs, and motivation. Further, Juhana (2014) revealed several characteristics of young learners. a) young learners have a great curiosity to try new things and build their own knowledge through working with things or ideas; b) young learners develop the meaning actively from direct experiences; c) young learners tend to be more focused on the real context and situation that can be directly observe and experience in the learning activities; and d) young learners have a short attention span and get bored easily with the class situation and activity.

Furthermore, the teachers must have knowledge about the use of instructional strategy to teach young learners in order to make them learn language effectively. The knowledge of instructional strategy is about the way teachers teach the subject as well as the ability to design interesting instructional strategy (Faisal, 2015). Thus, Çakir (2004) proposed several learning strategies that can be implemented in order to deal with the students' characteristics. a) teaching through visual is an effective strategy to be implemented since the students can develop their knowledge from what they see and hear through the visual media; b) teaching by giving context to the students will make them easier to understand and longer to remember if the material given; c) teaching through engaging and interesting activities will make the students to be more active to explore and build meaning from the experiences; d) teaching through fun and game to make the students feel comfortable, motivated, and involved in learning activities. Game must be in accordance with the learning material in order to make the students keep learning while playing game.

From the explanation above, it indicates that PCK is very important for the primary school English teachers in order to promote better language learning to young learners. As the reference of this study, there are several studies that have been conducted previously related to teach English to young learners. The study that conducted by Aini (2013) emphasized on the use of learning media in TEYL with aimed to investigate the use of instructional media by the teachers in teaching English to young learners, the problems that they encounter in using instructional media, and problem-solving of the media utilization challenges. This study used case study design to find out the real situation in primary school. The researcher conducted observation and interview to collect the data. Further, the result showed that there were four instructional media that were used in teaching English to young learners. The media were boards, relia, pictures, and books that were used depending on the learning objectives. Moreover, the teachers faced challenges in selecting and implementing the instructional media which was overcome by keep using the available media to teach. Whereas, the problems in implementing the media were solved by asking the technician to help, borrowing instructional media from other classes, and preparing back-up instructional media.

On the other hand, Rusiana and Nuraeningsih (2016) conducted a study that emphasize on TEYL through traditional game with aim to find out the the effetiveness of traditional game in English teaching and learning. This study was conducted at SDIT Lukman al Hakim of fourth grader students with 19 students as the participants. This study belonged to quasi-experimental with one control group pre-test and post-test. The 


\section{PRASI JuRnal bahasa, SENI, dAN Pengalarannya \\ VOL. 15 | No. 02 | December 2020 \\ ISSN: Print 1693-6124 - Online 2614-1116}

Undiksha| DOI: http://dx.doi.org/10.23887/prasi.v15i02.28161 |https://ejournal.undiksha.ac.id/index.php/PRASI

researcher used pre-test and post-test as the instruments to collect the data in this study. This study used two games namely Gedrik and betengan. The result showed that traditional games were effective to be implemented in teaching English to young learners. As the result of that, the researcher suggested the English teacher to implement game in teaching English to young learners.

In addition, the study was conducted by Putra (2015) which examined the teacher in creating a positive English language teaching and learning environment in the EYL classroom setting. This study was conducted in order to know how YLLs teachers of English comprehend the concept "positive English language teaching and learning environment" and to observe the efforts of YLLs teachers of English in establishing such an environment in the classroom setting. This study was implemented qualitative research design. The data was collected by using observation and interview in which the result showed that YLLs teachers of English were actually aware of the importance of the existence of a positive English language teaching and learning environment to support the success of English learning in the EYL classroom setting. Further, it was also found that such an environment could be created by the influence of YLLs teachers' teaching style, the physical environment of the classroom and the consideration of the use of their learners' native language in class.

Similarly, Artini (2017) conducted a study entitled Rich Language Learning Environment and Young Learners' Literacy Skills in English with aimed to develop a rich language-learning environment to help primary school students develop their literacy skills in English. The study was conducted by involving 12 teachers and 520 students in six primary school in Bali. In order to collect the data, questionnaires, observation, interview, English literacy tests, and students' literacy journals were used as the instruments. Thus, the result revealed that the readability of the materials is in the high category and there was a significant impact on students' literacy skills because of the systematic exposure to the materials.

Another study, which is about TEYL that combined with local culture in Bali conducted by Padmadewi et al. (2009) with the title "Model Konseptual Pembelajaran Bahasa Inggris Berbasis Budaya Untuk Sekolah Dasar Di Bali." The study belonged to the R\&D research design, which was proposed to produce an English learning model that is based on local culture for primary schools in Buleleng in the first year. The data were collected by using questionnaires, document analysis and interview which were then triangulated using expert judgments. The data analysis generated a conceptual English learning model that contains a set of competency standards, a set of basic competencies, approaches and methods/strategies of English teaching and learning, a list of themes/ materials, as well as assessments.

Other research conducted by Agustini, Artini, and Padmadewi (2019) was about the teachers' perception and classroom practice of constructivism values in primary schools in Badung regency. The objectives of this study were to describe the teachers' perceptions on the concept, implementation, and impact of the constructivism values, to describe the way teachers practice and implement the constructivism values, and to find out the relation of the teachers' perceptions and practice about constructivism values in the classroom. This study belonged to embeded mixed method in which the data was dominantly quantitative than qualitative and the data were explained descriptively and quantitatively. The result of this study showed that the teachers had strong perception 
and the implementation of constructivism values was in the low categorization. It can be inferred that the relationship between teachers' perception and classroom practice of constructivism values was inconsistent.

Similarly, the same study was conducted by Listyariani, Artini, and Padmadewi (2018) in order to investigate the teachers' perceptions nad implementation of teaching English for young learners in public primary schools in Jembrana subdistrict as well as the problems encountered by teachers in teaching English in the classroom. The instruments that were used to collect the data were questinnaire, rating scales, observation sheets, and interviews guide. This study belonged to embeded mixed method research design with dominant qualitative. The result revealed that the teachers' perceptions were strongly positive toward teaching English for young learners. Whereas, the implementation of TEYL was mostly deal with the component "teaching through activity" that was very high. Moreover, from the interviews, the main problesm that were encountered by the teachers were the difficulty to teach pronunciation, limited learning sources, limited time for preparing lesson, and lack of various learning activities. Thus, the government was suggested to provide English teachers with professional development on practical guidance of TEYL and sufficient learning sources.

Further, the previous studies have found the teachers' pedagogical aspect and the perception as well as the implementation of teachers' pedagogical knowledge in teaching English to young learners. However, those studies did not emphasize on the consistency between the teacher's perceptions and implementation in terms of pedagogical content knowledge. Thus, research on teacher's perceptions and implementation of PCK in teaching English to young learners need to be conducted. The teacher's perception about something will affect the way they teach. Unfortunately, the perceptions and implementation are not always directly proportional (Utami, Prestridge, Saukah, \& Hamied, 2019). There is possibility where the teachers have positive perception about concept of English language learning but do not implement it in the class. Therefore, the research that emphasizes on the consistency between teachers' perceptions and implementation of PCK need to be conducted in order to know the relationship between the teachers' perceptions and implementation of PCK. This research will examine this issue by involving primary school English teachers in Buleleng regency.

However, those studies did not emphasize on pedagogical content knowledge, let alone emphasizing the consistency between the teachers' perception and implementation in terms of pedagogical content knowledge. Thus, the research problems of this study were; 1 . How are the perceptions of primary school English teachers in Buleleng toward pedagogical content knowledge of teaching English to young learners?, 2. How is the implementation of pedagogical content knowledge in teaching English to young learners by primary school English teachers in Buleleng?, and 3. How is the consistency between perceptions and implementation of pedagogical in teaching English to young learners by primary English teachers in Buleleng?.

\section{RESEARCH METHOD}

This study belonged to mixed-method design. The type of mixed method used in this study was an embedded mixed method which was dominated by qualitative. In this study, the researcher combined one set of data with the other set of data in order to support each other. The secondary data was embedded in the larger study which had different 


\section{PRASI JURnal Bahasa, SENI, DAN PENGAJARANNYA \\ VOL. 15 | No. 02 | December 2020 \\ ISSN: Print 1693-6124 - Online 2614-1116}

Undiksha | DOI: http://dx.doi.org/10.23887/prasi.v15i02.28161 | https://ejournal.undiksha.ac.id/index.php/PRASI

data form as the primary database and the secondary database provided supporting role in this study (Cresswell, 2012). There were two types of data, namely qualitative and quantitative data.

The subject of this study were three primary school English teachers from three different schools in Buleleng regency. The subject was selected by using Convenience sampling or availability sampling which was the specific type of non-probability sampling that relies on collecting data from the members of the population who are ready to participate in the study. Generally, this sampling technique is choosing the subject by considering the ease of accessibility and proximity to the researcher (Cresswell, 2012).

The objects of this study were the teachers' perceptions and implementation of PCK in teaching English to young learners, and the consistency between the teachers' perceptions and implementation of PCK in teaching English to young learners.

In collecting the data, several instruments were used in this study. The main instrument of this study was the researcher who was interacted directly with the subjects of the study. Besides, the researcher also observed the way teachers implement PCK in learning process, talking to the subjects of the research when interview, and taking note during the interview. In addition, questionnaire was used to collect the data about the teachers' perceptions about PCK, observation sheet was utilized to collect the data related to the teachers' implementation of PCK, interview guide was used to collect the deeper information related to the teachers perceptions and implementation of PCK in teaching English to young learners.

The data from questionnaire and observation sheet was analyzed by using quantitative and qualitative method analysis. The data from the questionnaire were analyzed quantitatively by calculating the circled score by the three teachers. Therefore, the mean score was measured to get the clear categorization. Besides, the data from observation sheet were analyzed by using quantitative analysis in which the frequency of the implementation of PCK were calculated. Qualitative analysis was also used to measure the mean score of the implementation of PCK. Furthermore, the results of the perceptions and implementation were categorized based on the level of categorization proposed by Koyan (2012).

Moreover, the consistency between the teachers' perceptions and implementation was confirmed by the result of the interview that analyzed by using interactive analysis model which was proposed by Miles dan Huberman (1994). There were 4 steps in this model, such as data collection, data reduction, data display and describing the conclusion of verification. These steps were related to each other. In displaying the data, the researcher may return to the data collection step until all the necessary data were collected. In drawing conclusions, the researcher may return to the data reduction when unwanted data was collected. Otherwise, when the researcher comes to draw the conclusion, she might return to the data collection when the result of the data analysis was not enough to answer the research problem. In data collection, the researcher collected the data from the observation sheet and the result of interview. Thus, the data were analyzed continuously in order to get the data to answer the research questions.

Further, in order to present the trusted results, verification of trustworthiness was conducted. In this step, the results of the teachers' perceptions and implementation as well as the consistency between teachers' perceptions and implementation of PCK were analyzed by using some theories. Furthermore, the results also interpreted based on the 
theories used in this research. The theories were the language awareness and language proficiency from Andrews (2001), the concept of young learners from Juhana (2014), the implementation of instructional strategy to teach English to young learners from Çakir (2004), and the use of several attempts that have an impact on students' achievement from Medwell et al. (2009). Therefore, after all process of the analysis, it indicated that the results of this study were trusted.

\section{FINDINGS AND DISCUSSION}

After analyzing the data, the result showed that the mean score of teachers' perceptions of PCK in teaching English to young learners was 3,929 which belonged to strong category. It indicated that the teachers have good understanding of PCK in teaching English to young learners. However, each component of PCK has different mean score and category as well. The first component which was knowledge of subject matter was in very strong category since the mean score was 4,095. It can be inferred that the teachers' knowledge related to the language awareness and language proficiency was very good. Moreover, the second component of PCK was the knowledge of young learners' characteristics. The teachers' perceptions about this knowledge was very strong because the mean score was 4,185. It showed that the teachers have very good knowledge related to the characteristics of young learners. Besides, they also have knowledge about how to deal with the characteristics of young learners in language learning. In contrast, the last component which was the use of instructional strategy for young learners got 3,507. This component got slightly lower mean score that the two components. Further, the teachers' perceptions related to the use of instructional strategy for young learners was strong. The result revealed that the teachers' have good knowledge as well as understanding related to the use of instructional strategy in teaching English to young learners.

The result of the observation showed that the implementation of PCK in teaching English to young learners done by the teachers was in a very low frequency with the mean score 10,323. It showed that the teachers' knowledge related to PCK was not well implemented in the classroom. Moreover, the component of PCK that got the highest mean score was subject matter knowledge. In subject matter knowledge, the mean score of the teachers' implementation of PCK was 24,500 which belonged to category of moderate frequency. It can be inferred that the teachers had implemented the knowledge related to language awareness and proficiency even though it was not maximal. Further, the knowledge of young learners' characteristics got the lowest mean score which was 2,167 . It made this component was categorized as very low frequency. From the result, it implied that the teachers lack to implement this component in the classroom. Similarly, the use instructional strategy to young learners was categorized as very low frequency since the means score was 4,030.

Based on the categorization of teachers' perceptions and implementation of PCK, it clearly showed that there was a significant gap between the teachers' perceptions and implementation. The teachers' perceptions of PCK was strong, meanwhile the implementation was very low frequency. Each component of PCK also showed significant gap. The gap between the teachers' perceptions and implementation of subject matter knowledge was not too significant. It is because the teachers' perceptions were very strong meanwhile the implementation was in moderate frequency. Moreover, the 


\section{PRASI JURnAL BAHASA, SENI, DAN PENGAJARANNYA \\ VOL. 15 | No. 02 | December 2020 \\ ISSN: Print 1693-6124 - Online 2614-1116}

Undiksha| DOI: http://dx.doi.org/10.23887/prasi.v15i02.28161 |https://ejournal.undiksha.ac.id/index.php/PRASI

second and third components showed significant gap. In the knowledge of young learners' characteristics, the teachers' perceptions were very strong, meanwhile the implementation showed very low frequency. In the other hand, the teachers' perceptions of the use of instructional strategy was strong, but the implementation was very low frequency. Further, it made there was a significant gap between the teachers' perceptions and implementation of PCK in teaching English to young learners.

Furthermore, it was found that the relation between the teachers' perceptions and implementation of PCK was no consistency. The relation from each component also showed inconsistency. In subject matter knowledge, there was found lack consistency between the teachers' perceptions and implementation. The relation between the teachers' perceptions and implementation of the knowledge of young learners' characteristics was no consistency. In the same way, no consistency also found between the teachers' perceptions and implementation of the use of instructional strategy in teaching English to young learners.

The result showed that the teachers' perceptions of the knowledge of subject matter was very strong. It can be inferred that the teachers have very good understanding related to the language awareness and language proficiency. By having a good understanding of language awareness and language proficiency, the teachers can promote better learning for the students. It is in line with Andrews (2001) who revealed that the teacher who has a good language awareness will lead to the effectiveness and better language learning since the teacher will provide extensive input for the students. Besides, Canh and Renandya (2017) also stated that language proficiency is the key to the success of language learning. The teachers with high level of language proficiency will give better understanding about the material since they are able to use the language to explain the material in spoken and written form fluently.

Similarly, the teachers also had very strong perceptions of the knowledge of young learners' characteristics. It showed that the teachers' understanding toward this component was very good. By having this knowledge, the teachers can take the advantages since they can design learning strategy that suitable for the students' characteristics. It was in line with Musthafa (2010) that knowledge of young learners' characteristics is an important requirement in designing effective instruction. In relation to this, Aini (2013) stated that the effective instruction refers to the use of interesting activities and learning media. Thus, the teachers who have a good understanding of the characteristics of young learners can design interesting activities that suitable for the young learners which will lead the students to acquire specified skills, knowledge and attitudes effectively.

In the last component, the result showed teachers had strong perceptions toward "The Use of Instructional Strategy for Young Learners. It can be inferred that the teachers' have good understanding about the implementation of learning strategies in the classroom to teach English to young learners. The teachers must design the instructional strategy by regarding to the young learners' characteristics in order to make the learn language effectively. In line with it, Çakir (2004) stated that the young learners' tend to understand language more easily when they are feel comfortable and motivated in learning activity. Moreover, creating an enjoyable and fun learning activities that emphasize on the physical activity can make the students learn the language better since they can practice their language during the activity. Thus, it can be inferred that the 
teachers who have a good understanding toward the use of instructional strategy is expected to give enjoyable yet meaningful learning activity.

Further, it was found that the implementation of PCK in the classroom was very low frequency since the mean score was 10,232. It can be inferred that the teachers did not implement the PCK maximally in the classroom.

The implementation of the first component in PCK which was "The Knowledge of Subject Matter" that related to the language awareness and proficiency belonged to category of moderate frequency. It can be inferred that the teachers have implemented it during learning process even though it was not maximal. During learning process, the teachers often used English fluently to explain the material and give instruction to the students. Even though it still needs to be translated in order to make the students understand. In addition, in writing English words or sentences in the whiteboard, the teachers did not make any error. Besides, the teachers also corrected the students' mispronunciation, misspelling, or word choice and grammar error that occurred in the classroom. Thus, it implied that the teachers already tried to communicate by using English as well as correcting students' error in grammar, pronunciation, and spelling in order to make the students familiar with English language.

In contrast to the first component, the implementation of the second component which was "The Knowledge of Young Learners Characteristics" which was in category of very low frequency. It implied that the teachers seemed did not implement this component optimally. Actually, the teachers have tried to facilitate the students' characteristics by such activities and strategies. During the observation the teachers did not provide new learning experiences to the students. The teachers tend to use monotonous activities that made the students bored.

In the same way, teachers' implementation about "The Knowledge of Instructional Strategy" was also in category of very low frequency. It indicated that the teachers did not possess much attempts in designing interesting and enjoyable learning activities as well as preparing learning media in teaching English to young learners. Additionally, during the observation, only one teacher who provides game, and it was only implemented in one meeting. It can be inferred that game was rarely to be used in learning process. In fact, teaching English by using interesting strategy and learning media will encourage the students to involve in the learning activities and learn the language effectively (Aini, 2013; Çakir, 2004).

Furthermore, the result from the identification of consistency showed that the teachers' perceptions and implementation was no consistency. It implied that there was incompatible between the perceptions and the implementation that need to be clarified by using the result of interview.

The result of consistency between perceptions and implementation showed that there was lack consistency in the first component of PCK "Knowledge of Subject Matter". From the result of interview, it can be inferred that the teachers' have difficulty in using English during learning process. All of the teachers clearly stated that they still use English but in certain circumstances and only at certain grade. This problem appears since the students do not know many vocabularies in English, so they difficult understand at the teacher when they speak English during learning process. Thus, in order to make the students easier to understand the material, the teachers used Bahasa Indonesia during learning process. The result in line with Ostovar-Namaghi and Norouzi (2015) who found 


\section{PRASI JuRnal BAHASA, SENI, DAN PENGaJARANNYA \\ VOL. 15 | No. 02 | December 2020 \\ ISSN: Print 1693-6124 - Online 2614-1116}

Undiksha| DOI: http://dx.doi.org/10.23887/prasi.v15i02.28161 |https://ejournal.undiksha.ac.id/index.php/PRASI

that the teachers can use mother tongue to give understandable input for the students since the students develop their competence from the teachers' extensive understandable input. In addition, they also found that the teachers can use the mother tongue to help students to understand certain material if the students have comprehension problem because of target language is hard to understand.

Further, related to the second component which was "The knowledge of Young Learners Characteristics", the result of the identification of consistency showed no consistency between the perceptions and implementation. From the interview, the teachers clearly stated that the learning activities tend to be monotonous because of some factors. The teachers stated that the factors were the school did not provide compatible learning facilities and it was difficult to design learning media that related to the material. Moreover, the teachers seemed could not deal with the students' characteristics which was very curious and can build knowledge from working with things and ideas. From the interview, the teachers clarified that the students cannot be taught only by giving them idea or things and ask them to work and create meaning from it. The teachers argued that the problem comes from the students themselves because they still need guidance in learning. Additionally, students lack of English vocabulary will make them difficult to understand even develop their understanding individually without being assisted by the teacher.

In the last component of PCK which was "The Knowledge of Instructional Strategy", the result from identification of consistency clearly showed that there was no consistency between the perceptions and implementation of this component. From the interview, the teachers clearly stated that they are rarely to use media visual in teaching English. It was because there is no facility to support the implementation of visual media in the classroom. Besides, the teachers also found difficulty in finding and designing appropriate media visual that related to the material. It is in line with Widya (2016) who found that lack of instructional media becomes one of the challenges that is faced by the teachers in teaching English to young learners.

Moreover, the teachers do not provide an enjoyable learning environment by using game and song. The result of interview clearly showed that the teachers admitted that provide song and game is important in order to make the students more excited and eager to learn. However, the teachers rarely implemented game and song in the classroom. It was because they feel difficult to manage the class when playing game and the teachers did not implement it because the students' understanding toward the material is more emphasized.

Thus, the problems encountered by the teachers in implementing PCK were found by conducting interview. In the first component which was "The Knowledge of Subject Matter", the teachers found difficulty in using English to explain the material to the students. Additionally, the students' lack of vocabulary made the teachers difficult to use English in the classroom. Further, related to the second component which was "The Knowledge of young learners' characteristics", the teachers have problem in designing the activity to facilitate the students' characteristics in learning English. It occured due to a reason, which was the students still need to be guided and assisted in learning English. Finally, the third component which was "The Use of Instructional Strategy", the teachers found difficulty in using media visual. It happened due to unavailability of facility in the schools. The teachers also feel difficult to find learning media that related 
to the material. Moreover, the teachers rarely use game because as the teachers have said that it is difficult to manage the students while playing game. Those are several problems encountered by the teachers in implementing PCK in the classroom. They did not implement the components of PCK well in the classroom, even though they had strong perceptions on PCK. Due to several problems which previously mentioned, they might appear as the obstacles in implementing the components of PCK in teaching English to young learners.

Therefore, it can be concluded that there was no consistency between the teachers' perceptions and implementation of PCK in teaching English to young learners. It indicates that teachers' perceptions and implementation is not directly proportional. Even though the teachers' perceptions of PCK is strong, it do not mean that the teachers are able to implement PCK well in the classroom. This study supports the findings in Utami et al. (2019) which conducted a study in Indonesian context, that perceptions and implementation of English teacher may not always proportional. Discrepancy between what is perceived and practiced by English teachers is much influenced by the degree of teacher professional enthusiasm. The pattern in the study by Utami, et al (2019) shows that the higher professional enthusiasm the higher consistency of perceptions and implementation prevails. Although the current study does not directly support the mentioned pattern, but it indeed re-establishes the idea that teachers' perception and implementation may be inconsistent.

\section{CONCLUSION}

The primary school English teachers in Buleleng have strong perceptions toward PCK. The mean score is 3,929 which belonged to interval 3,3335 $\leq \mathrm{M} \leq 4,0005$. It implied that the teachers have good knowledge and understanding toward all of the components of Pedagogical Content Knowledge to teach English to young learners.

The primary school English teachers in Buleleng have very low frequency related to the implementation of PCK in teaching English to young learners. The mean score is 10,232 which belonged to interval $0,000 \leq M \leq 14,583$. It implied that the teachers did not implement all of the components of PCK well in teaching English to young learners.

The consistency measurement between teachers' perceptions and implementation of PCK in teaching English to young learners showed no consistency. There is significant gap between the result of teachers' perceptions and implementation. This no consistency happens because there are several problems during the implementation of PCK in the classroom. The problems encountered by the teachers including the difficulty to use English in the classroom, to use media due to lack of schools' facilities, to choose learning media that related to learning material, and to manage the class when using game in learning process.

Since there is no consistency between the teachers' perceptions and implementation of PCK in teaching English to young learners, the teachers must improve their knowledge. Based on the results, the teachers must enrich their knowledge related to young learners' characteristics and the use of instructional strategy to teach English for young learners. The teachers should facilitate the students' characteristics by providing them with such interesting and enjoyable learning activities. Additionally, the teachers must give more efforts in designing enjoyable and meaningful learning activity for the students in order to make language learning run effectively. Therefore, the teachers are 


\section{PRASI JuRnal bahasa, SENI, dAN PEngalarannya \\ VOL. 15 | No. 02 | December 2020 \\ ISSN: Print 1693-6124 - Online 2614-1116}

Undiksha | DOI: http://dx.doi.org/10.23887/prasi.v15i02.28161 | https://ejournal.undiksha.ac.id/index.php/PRASI

suggested to enrich their knowledge of PCK in teaching English to young learners by attending certain professional development program related to Teaching English to Young Learners.

This research emphasized on on the teachers' perceptions, implementation, and the consistency of the teachers' perceptions and implementation of PCK in teaching English to young learners. This research involved limited number of participants to reveal their perceptions and implementation of PCK. It is suggested to conduct research with same topic with wider scope, using more participants and different procedures of collecting and analyzing data to gather more information.

\section{REFERENCES}

Agustini, N. W. W., Artini, L. P., \& Padmadewi, N. N. 2019. English Teachers'Perceptions and Classroom Practices On Constructivism Values in Primary Schools in Badung Regency, 7(2), 1-11. https://doi.org/DOI: 10.23887/jpbi.v7i2.2722

Aini, W. N. 2013. Instructional Media in Teaching English to Young Learners: A Case Study in Elementary Schools in Kuningan, (1972), 196-205. Retrieved from https://ejournal.upi.edu/index.php/L-E/article/view/350

Andrews, S. 2001. The Language Awareness of the L2 Teacher: Its Impact Upon Pedagogical Practice. https://doi.org/10.1080/09658410108667027

Artini, L. P. 2017. Rich Language Learning Environment And Young Learners ' Literacy Skills In English, 11(May), 19-24. https://doi.org/10.21512/lc.v11i1.1587

Çakir, İ. 2004. Designing Activities Classrooms for Young Learners in EFL Classroom, 3, 101-112. Retrieved from http://www.gefad.gazi.edu.tr/tr/download/articlefile/77293

Canh, L. Van, \& Renandya, W. A. 2017. Teachers' English Proficiency and Classroom Language Use: A Conversation Analysis Study. RELC Journal, 48(1), 67-81. https://doi.org/10.1177/0033688217690935

Creswell, J.W. 2012. Educational Research Planning, Conducting, and Evaluating Quantitative and Qualitative Research. Fourth Edition. USA: Pearson Education, Inc.

Faisal, F. 2015. Pedagogical Content Knowledge in English Language Teaching in Indonesia (a preliminary analysis), (November 2014). Retrieved from https://digilib.ump.ac.id/files/disk1/23/jhptump-ump-gdl-faisal-1116-1-faisal.pdf

Ghasemi, B., \& Hashemi, M. 2011. Foreign language learning during childhood. Procedia - Social and Behavioral Sciences, 28, 872-876. https://doi.org/10.1016/j.sbspro.2011.11.160 
Habibi, A., \& Sofwan, M. 2015. Teachers of English for Young Learners : An Analysis on Their English Proficiency and Profile. Retrieved from https://www.researchgate.net/publication/324184294\%0ATeachers

Juhana. 2014. Teaching English to Young Learners : Some Points to be Considered, 02 (01), 43-46. Retrieved from https://www.ajouronline.com/index.php/AJEEL/article/view/575

Listyariani, N. P. R., Artini, L. P., \& Padmadewi, N. N. 2018. Teachers ' Perceptions Of Teaching English For Young Learners And The Implementation In Public Primary Schools In Jembrana Sub-District. Jurnal Pendidikan Bahasa Inggris Indonesia, 6(2), 1-10. https://doi.org/https://doi.org/10.23887/jpbi.v6i2.2710

Magnusson, S., Krajcik, J., \& Borko, H. 1999. Nature, Sources, and Development of Pedagogical Content Knowledge for Science Teaching, (May 2014). https://doi.org/10.1007/0-306-47217-1

Mahardhika, P. 2014. English Teaching Media In Class Implementing Curriculum 2013, (68), 177-180. Retrieved from 172694-EN-english-teaching-media-in-classimplements.pdf

Medwell, J., Wray, D., Minns, H., Griffiths, V., \& Coates, E. 2009. Primary English: Teaching Theory and Practice Fourth edition (4 edition). Learning Matters Ltd.

Musthafa, B. 2010. Teaching English to Young Learners in Indonesia: Essential Requirements, IV (2), 120-125. Retrieved from 5501436b8e67d956a31cf8303f520eeea7d4.pdf

Ostovar-Namaghi, S. A., \& Norouzi, S. 2015. First Language Use in Teaching a Foreign Language: Theoretical Perspectives and Empirical Findings. US-China Foreign Language, 13(9), 615-622. https://doi.org/10.17265/1539-8080/2015.09.001

Padmadewi, N. N., Nitiasih, P. K., \& Artini, L. P. 2009. Model Konseptual Pembelajaran Bahasa Inggris Berbasis Budaya Untuk Sekolah Dasar Di Bali. Jurnal Pendidikan Dan Pengajaran, (67), 170-177.

Putra, J. R. 2015. Creating a Positive English Language Teaching and Learning Environment in EYL Classroom Setting, (218), 218-261. Retrieved from https://eprints.umk.ac.id/340/28/PROCEEDING_TEYLIN_2.224-267.pdf

Reddy, M. S. 2016. Importance of English Language in today' s World Introduction : International Journal of Academic Research, 3(4), 179-184. Retrieved from www.ijar.org.in

Rusiana, \& Nuraeningsih. 2016. Teaching English To Young Learners Through. Jurnal 


\section{PRASI JuRnal BAHASA, SENI, DAN PENGAJARANNYA \\ VOL. 15 | No. 02 | December 2020 \\ ISSN: Print 1693-6124 - Online 2614-1116}

Undiksha | DOI: http://dx.doi.org/10.23887/prasi.v15i02.28161 | https://ejournal.undiksha.ac.id/index.php/PRASI

of Language and Literature, 2(April), 193-200. https://doi.org/https://doi.org/10.15294/lc.v10i2.5729

Shin, J. K. 2009. Teaching English to Young Learners Module I : Learning \& Teaching Styles for Primary Students. Retrieved from https://eteachabroad.com/wpcontent/uploads/TeachingEnglishtoYoungLearnersSHIN.pdf

Shulman, L. E. E. S. 1986. Those Who Understand: Knowledge Growth in Teaching, 15(2), 4-14.

Utami, I. G. A. L. P., Prestridge, S., Saukah, A., \& Hamied, F. A. 2019. Continuing Professional Development and teachers' perceptions and practices - A tenable relationship. Indonesian Journal of Applied Linguistics, 9(1), 108-118. https://doi.org/10.17509/ijal.v9i1.12463

Widya, V. T. R. 2016. Teachers' Challenges in Teaching English to Young Learners in Rural Public Primary Schools in Salatiga. Retrieved from https://repository.uksw.edu/bitstream/123456789/9473/2/T1_112012033_Full text.pdf 